\title{
THE EFFECT OF REFUGEE CRISIS ON EU ENLARGEMENT
}

\section{Deniz TEKIN APAYDIN *}

\section{Abstract}

The crisis has marked especially the last decade of the EU, with the refugee crisis being the last wave thereof. The refugee crisis is perhaps having a more aggravated effect on the EU, with the contribution of the prior ones. With the rising Euroscepticism and xenophobia, the EU enlargement policy is particularly under threat. Examining the response of the EU to the prior crisis situations, it is observed that the way out formula has always orbited around 'more Europe' approach. Bearing this conclusion in mind, this paper argues that the EU enlargement policy requires a way-out formula from the refugee crisis, which should be developed by placing the EU citizens and their will into its centre. Ultimately, their will reflects directly or indirectly to the European Parliament and the Council of the EU, the two leading decision-making institutions of the EU. Moreover, as the decision-making procedure followed during enlargement process is subject to an intergovernmental method, this 'will' is gaining more significance. It is also suggested that the will of the EU citizens may be malformed due to the asymmetric information they are exposed to. This may eventually lead to the disintegration of the EU, in analogy with Akerlof's infamous "Market for 'Lemons"' illustration that depicts the consequence of asymmetric information.

Keywords: Refugee crisis, EU enlargement policy, Euroscepticism, asymmetric information, EU public opinion, disintegration.

\section{MÜLTECI KRIZININ AB GENIŞLEMESINE ETKILERI}

$$
\ddot{O} z
$$

Son dalgasını mülteci krizi oluşturmak üzere, AB'nin özellikle son on yılına krizler damgasını vurmuş durumdadır. Önceki krizlerin katkısıyla, mülteci krizinin AB üzerinde daha ă̆ırlaşmış bir etki yarattı̆̆ söylenebilir. Artan AB 
karşıtlığı ve yabancı düşmanlı̆̆ının da etkisiyle, AB genişleme politikası bilhassa tehdit altındadır. AB'nin daha önceki krizlere karşı tavrı incelendiğinde, çıkış yolu formülünün hep 'daha fazla Avrupa' yaklaşımı yörüngesinde geliştirildiği görülmektedir. Buradan yola çıkarak, bu çalışma, AB genişleme politikasının, mülteci krizinden çıkmak için, AB vatandaşlarını ve onların tercihlerini merkeze koyacak bir formül geliştirilmesi gerektiği görüşünü ortaya koymaktadır. Sonuç olarak onların tercihleri, AB'nin temel karar alma kurumlarl olan Avrupa Parlamentosu ve AB Konseyi'ne doğrudan ya da dolaylı olarak yansımaktadır. Üstelik genişleme sürecinde kullanılan karar alma mekanizması hükümetlerarası metoda tabi olduğu için bu 'tercihler' daha da önem kazanmaktadır. Aynı zamanda AB vatandaşlarının bu tercihlerinin maruz kaldıkları asimetrik bilgi nedeniyle sakatlanmış olabileceğ $i$ ileri sürülmektedir. Bu durum, nihayetinde, Akerlof'un asimetrik bilginin sonunu betimlediği meşhur 'Limonlar Piyasası' kurgusundaki gibi, AB'nin dă̆llmasına kadar gidebilir.

Anahtar Kelimeler: Mülteci krizi, AB genişleme politikası, AB karşıtllı̆̆l, asimetrik bilgi, AB kamuoyu, dă̆llma.

\section{Introduction}

Syrus $^{1}$, a Syrian Philosopher who lived in the $1^{\text {st }}$ Century BC, once said that 'miserrimum est arbitrio alterius vivere' (The ultimate misery is life at another's will). (thelatinlibrary.com) This is ironic in two ways: First, 22 centuries in, and his descendants are in a lethal effort to reach to Europe under what may be comparable to slavery conditions of the time. Second, many States have managed to, and many are waiting to be approved, to hand in a portion of their 'will' (sovereignty) to the hands of 'another'! (the EU)

This study aims to provide a fresh outlook to the effect of refugee crisis on the EU in general and the EU enlargement in particular. With this ambition in mind, firstly, some crisis that the EU has faced until now will be given briefly in an attempt to reveal what kind of an approach was employed in overcoming those crises. Secondly, the refugee crisis will be examined, with reference to its implications on the EU in general and the enlargement policy in particular. Thirdly, the infrastructural challenge on enlargement process in the EU will be presented highlighting the intergovernmental decision-making procedure employed. Next, the people of Europe and their opinion will be addressed as the key determinant to decide on the future of Europe. In this regard, the 'asymmetric information problem' inherited in 'democracy' will be examined

${ }^{1}$ Publilius Syrus was a philosopher/writer, who was enslaved and taken to Italy, then freed and educated by his master. 
with regard to the 'Asymmetric Information' theory of Akerlof. In conclusion, possible options for the EU to adopt in a search out of the refugee crisis and its implications will be presented.

The EU has been an experimental integration project from the onset, with a desire inter alia to "supersede ruinous nationalism and ensure peace" (Gilbert, 2012: 2). The integration process started in 1952 with six countries and in 65 years have evolved into an economic and political union of 28 member states. ${ }^{2}$ During this time, the EU has grown both vertically and horizontally simultaneously. That is to say, while enlarging geographically, it has also deepened and got more integrated. As its motto suggests EU has 'united in diversity'. Enlargement has been depicted as one of the most successful policies of the EU. It has contributed to the Union's external influence and identity. Especially the inclusion of 11 post-Communist States of Central and Eastern Europe has been given as one of the most important achievements of Enlargement Policy. However, the transformation of the inner six of the ECSC into the EU 28 of Lisbon, has not been straightforward and definitely not without any crisis. The EU have lately stuck in a refugee crisis, which has an adverse effect on enlargement policy. Before getting into the details of refugee crisis, and its effect on the EU enlargement, it would be useful to initially picture briefly what crisis have the EU faced up until now.

\section{The Crisis of the $\mathbf{E U}$}

The EU is no stranger to crisis. There may be many occasions which can be regarded as crisis, but for the sake of consistency, only some of the most important ones will be mentioned. Crisis here, refer to the tough times where the Union is tested against its policies and values.

The first crisis to mention is what is generally referred as the 'Empty Chair Crisis'. It was caused by de Gaulle's decision to suspend French government representatives to join (the then EEC) Community body meetings to protest a Commission proposal regarding Common Agricultural Policy and empowerment of the Parliament. This triggered a strain between de Gaulle's more intergovernmental approach and others' supranationalist approach towards the future design of the EU. De Gaulle's purpose was taken as an effort to lead the integration process and meanwhile to maintain a strong French influence. The emphasis of his attitude was in favour of State sovereignty over Community power. This was resolved through the Luxembourg Compromise of 1966, which formulated a midway of 'vital national interest' defence for

2 The first enlargement was in 1973 with the accession of Denmark, Ireland and the United Kingdom. The fifth enlargement of 2004 was the greatest ever with the accession of ten States. The seventh enlargement of 2013 was the last one, by which the EU Members have reached to 28 with the accession of Croatia. 
States to be able to by-pass decisions taken by qualified majority voting. ${ }^{3}$ Since the Member States (MSs) considered any subject as essential for their national interest, this compromise in effect led to decisions taken by unanimity. This design decelerated the Community's decision making mechanism and caused it to operate very sluggishly. What is more, only the lowest common denominator acceptable to all MSs could be enacted. This crisis and the follow up compromise tested the willingness of the MSs on further integration. Although the Luxembourg Compromise had a negative effect on the European integration in the short term, it was perhaps necessary to experience the reach of an intergovernmental structure, to appreciate the potential and necessity of a supranational structure. Therefore, during the nearly 20 years of its exercise, the Luxembourg Compromise proved the necessity to make a choice and accept QMV (qualified majority voting/supranational method) if effectiveness and further integration is desired. (Yataganas, 2001:14) The roots of this crisis was counter-challenged by 'more Europe' formulation in the long run.

The Treaty establishing a Constitution for Europe was signed in Rome on the $29^{\text {th }}$ of October 2004. The entry into force of any EU Treaty is subject to its ratification by the MSs. The ratification process varies from State to State depending on national constitutional requirements. Most MSs require parliamentary votes only, where some hold referendum. Holding referendum has been widely preferred by the MSs due to the important and sensitive nature of the subject in question. The rejection of the Treaty in French and later in Dutch referendum brought the ratification process to an end. Hence the Constitutional Treaty Project had to be abandoned. This was a political damage to the EU. It was a message from some MSs and EU citizens that they are not willing to accept a more integrated structure, at least not in the way prescribed by the Constitutional Treaty. It is generally accepted that many were not comfortable with the very 'Stately' connotations of the Constitutional Treatyperhaps in the first place with its name. This was again another test for the MSs' willingness for further integration. Following a period of reflection and the result of an IGC (Intergovernmental Conference) a reform treaty has been drafted and signed in 2007. The wounds have been healed and the confidence was partly restored by the ratification of the Lisbon Treaty by the MSs by 2009 . It is worth noting that this process has also been challenging due to Irish veto in 2008 referenda, which was later reversed in a second one in 2009. Nevertheless, the answer to this crisis has also been 'more Europe'.

The global financial crisis that started in 2007 led to an economic recession. The flawed data provided made it impossible to predict the true scale of

3 For more information, see: CVCE.EU "The Luxembourg Compromise (1966)", and Eurofound "Luxembourg Compromise". 
financial situation in Greece. (Financial Times, 2010) Although the exact figures were unknown, the Greek economy was a serious concern at the time the Lisbon Treaty has entered into force. The alarm bells started to ring as the Greek government revealed that its 2009 budget deficit would be more than four times higher than the recommended maximum limit of $3 \%$ of the Gross Domestic Product under the rules of Economic and Monetary Union (EMU). ${ }^{4}$ In May 2010 the Eurozone countries and the IMF agreed a bailout programme for Greece, provided that some austerity measures are implemented, which led to severe protests by the Greek public. The Euro crisis has been highly consequential for the EU as it threatened the future of the EMU. The impact of a possible Greek departure from the Eurozone would not only harm Greece, but also weaken the credibility and stability of the Eurozone. The inter-connection between the Monetary Union and the Internal Market could cause the whole EU Project to collapse. Yet it was primarily an issue for the Eurozone Members. As a result of various efforts, especially the European Council's Euro Summits, (Dinan, 2016) the way out of the crisis has been addressed as 'more Europe': the Monetary Union has been strengthened by, inter alia, the establishment of a rudimentary banking union and fiscal union. The solution was once again deeper political and economic integration.

The Ukraine unrest began with the strain between the pro-EU and proRussian groups upon the Ukrainian Government's suspension of the association agreement with the EU in 2013. It was further triggered and became a crisis when Russia annexed Crimea and support militant separatists in the east of Ukraine. Ukraine is neither a MS, nor a candidate, but a significant actor for the EU's neighbourhood policy on Eastern Partnership. And this time the crisis posed no threat to the future of the EU, but rather tested its solidarity and perhaps the effectiveness of its foreign policy. (Dinan, 2016:1239) Although all MSs condemned the Russian annexation of Crimea, some of them were reluctant to agreeing to impose economic sanctions on Russia due to the costs to be incurred. Following various meetings and perhaps with the outraged reaction to the downing of a Malaysian Airlines flight over eastern Ukraine (in July 2014), allegedly by separatists armed with Russian missiles, strengthen the common EU position and gradually intensified the sanctions against Russia. The failure to duly react to the Russian aggression would have impaired the credibility of the EU as a political union. Building and announcing such consensus represented empowered EU solidarity and also reinforced the image of unity between the Western and the Eastern Europe, the latter of which is deemed to be more tolerant towards Russia by virtue of historical ties. Yet again, this crisis was resolved through 'more Europe' formula.

${ }^{4}$ For more information on Greek financial situation see: KINDREICH (2017); The Guardian (WEARDEN, 2010); The New York Times, (JOLLY, 2010) 


\section{The Refugee Crisis}

Before the economic crisis and the Ukraine crisis could come to an end, the EU was faced with a migration crisis. ${ }^{5}$ There has been an increase in migration in the aftermath of Arab Spring since 2010, but it was not really a crisis until the situation rapidly deteriorated in Syria and a massive influx of refugees ended up at the doorstep of the EU. (See: Chart 1 and Chart 3) (IOM, The Global Migration Trends Factsheet, 2015:8) ${ }^{6}$ The death toll during the rush to Europe has been devastating. According to the data provided by the International Organisation for Migration (IOM) 3.072 people died or disappeared in the Mediterranean while trying to migrate to Europe in 2014 and a further 3.692 in 2015. (IOM Press Release, 2016) By the $28^{\text {th }}$ of October 2016, an estimated of 3930 migrants died or gone missing in the Mediterranean alone. (IOM Press Release, 2016) It is nearly 13 people per day! (IOM Press Release, 2016) According to the Office of the United Nations High Commissioner for Refugees top three nationalities of arrivals from Mediterranean Sea in 2015 are Syrians with 50\%, Afghans with 21\% and Iraqis with 9\%. (UNCHR, Global Trends, 2015:34) The lethal efforts to reach Europe were perhaps further encouraged by Merkel's statement in September 2015, declaring that Germany would not impede the migrants entering the country. ${ }^{7}$ (Skynews, 2015) Even though it represents a humanitarian cause, it also is an open invitation to migrants for a fatal journey to Europe.

The overwhelming extent of the migration crisis unfold the sad truth about the supposedly secure external borders of the EU, that they were tremendously porous. In addition to that the Dublin Regulation that sets the procedures for registering and processing asylum seekers as they enter the EU proved to be unworkable under the circumstances. While all the MSs were under the stress of the massive and sudden influx of migrants, some States were under more strain than the others. (See: Chart 2) For instance Greece and Italy were the main first destinations of the Mediterranean and the Balkan route. The relationship between Germany and Greece was already strained from the Euro crisis and both accused each other in the deteriorating situation. (Dinan, 2016:1241) Greece expected more support and solidarity, where Germany blamed Greece for not complying with Schengen obligations and securing its borders. The crisis posed many challenges for the EU from humanitarian to economic and security. Various measures are on the table for discussion and

\footnotetext{
${ }^{5}$ For all the following figures in this section see also annex: Refugee Crisis in Figures 6 "The number of refugees has seen a 55\% increase since the end of 2011, largely due to the civil conflict in the Syrian Arab Republic. During 2015 alone, some 1.8 million people became refugees, compared to 1.2 million in 2014." The Global Migration Trends Factsheet2015.
}

7 This call was identified as the "pull factor" of the migration crisis by Dinan. (2016:1240) 
action, such as the establishment of a temporary relocation system, co-operating with the third countries of interest such as Turkey, fighting human trafficking and smuggling, and setting up of a 'European Coastguard' for saving lives at sea. (Carrera et al., 2015) As of today, the crisis and its implications are far from resolved.

\section{The Implications of the Refugee Crisis}

The refugee crisis poses various challenges to the EU and its policies. Although these implications will be presented as the results of the "refugee crisis' per se, it is worth to mention that some of them are rather the consequences of the ongoing and overlapping crisis in the EU within the last decade.

\section{The Rise of Euroscepticism}

Euroscepticism was once seen as a "British disease" but the ongoing crisis climate in the EU gave rise to an alarming rise in Euroscepticism. (ECFR, 2013:1) And as the European Council on Foreign Relations puts it: "it is contagious"! (ECFR, 2013:1) According to the Eurobarometer polls within the period between 2007 and 2012, since the beginning of the Euro crisis, trust in the European Union has fallen from +10 to $-22 \%$ in France, from +20 to $-29 \%$ in Germany, from +30 to $-22 \%$ in Italy, from +42 to $-52 \%$ in Spain, from +50 to $+6 \%$ in Poland, and from -13 to $-49 \%$ in the United Kingdom. (ECFR, 2013:3)

The soaring Euroscepticism is observable by the findings of survey results. According to the findings of a Spring 2016 survey by Pew Research Centre carried out in ten MSs, the EU favourability is the highest in Poland by $72 \%$, where it is lowest in Greece by $27 \%$, followed by France by $38 \%$ and the UK by $44 \%$ in Europe. (See: Chart 4) Another set of findings reveal that the people of Europe have a rather negative approach to more powers conferred to the Union. Where more or less quarter of the people think that division of powers between the EU and the national governments should remain the same, relatively less people believe that national governments should transfer more powers to the EU. Only $6 \%$ of the Britons, $8 \%$ of the Greek and $9 \%$ of the Polish are in favour of a closer Union, where $68 \%$ of the Greek, $65 \%$ of the Britons and $47 \%$ of the Swedish believe some powers should be returned to national governments. (See: Chart 5) The people who are backing further integration in the EU most are the French with $34 \%$, and the Spanish with 30 $\%$ followed by Germans with $26 \%$. (See: Chart 5) The same survey expose the reaction of the European people as regards the refugee policies of the EU. It is no surprise that the highest rates of disapproval of such policies is observed in Greece. (See: Chart 6) 
According to the Spring 2016 results of the Eurobarometer survey only 33 $\%$ of the Europeans trust in the EU. (See: Chart 8) However it is also striking that Europeans do not also trust their national parliaments and governments even more than they do not to the EU. This is a very pessimist outlook indicating the lack of trust and belief to all political institutions.

Euroscepticism by the Europeans can also be monitored from the European Parliament. Observing the new configuration of the Parliament after the 2014 elections the Eurosceptic influance can be noted. Around 100 of the MEPs are strong Eurosceptics, where nearly a further 330 are of the right wing. (See: Chart 9) Many studies have already established the correlation between the crisis and the rise of Eurosceptic votes. It was also submitted that voters who are opposed to inter alia "liberal immigration policies are more likely to support the Eurosceptic right." (Hobolt and de Vries, 2016: 510)

\section{The Risk Posed on the EU Identity}

Inversely correlated with each other, the rise of EU scepticism reflects as the fall of EU identity for Europeans. Some Europeans percieve the "collective identity" of the EU as threat to their national identity and national sovereignty. (Hakhverdian et al. 2013: 525) The EU's failure to respond effectively to counter-challenge the effects of the crisis has led the people to question the benefits of being part of the EU. Immigration, terrorism and economic situation are the current top three concerns of the Europeans (48, 39 and $19 \%$ respectively). (Standard Eurobarometer 85, 2016:4)

The rise of extreme right-wing movements in national politics of the MSs is the proof of such deviation from the European identity. Mostly anti-immigrant and Eurosceptic far right national policies threaten the EU identity and image as well as the EU integration itself as they gain more public support day by day. (See: Chart 10) It is striking to observe that according to the results of the most recent national elections many once extreme right parties could make their way to the Parliament for the first time, and many got historical victories. The question is will it undo the EU?

\section{The Risk Posed on the EU Values}

Article 2 of the TEU provides: 'The Union is founded on the values for respect for human dignity, liberty, democracy, equality, the rule of law, and respect for human rights, including the rights of persons belonging to minorities. These values are common to the Member States in a society in which pluralizm, non-discrimination, tolerance, justice, solidarity and equality between women and men prevail. ${ }^{8}$ The refugee crisis also posed a challenge on

8 The parts written in italic is changed by the present author for the purpose of adding emphasis. 
the values of the EU given in the Art.2 of the TEU. It induced the questioning of those values, particularly of human dignity, human rights, pluralizm, nondiscrimination and solidarity, since the case for refugees has an, inter alia, humanitarian motive of protecting others from persecution.

\section{The Risks Posed on the Schengen Project}

The Schengen Borders Code Art. 28 provides Member States with the right to temporarily re-introducing border control at the internal borders in case of a serious threat to public policy or internal security. After September 2015 several Schengen countries (Germany, Austria, Slovenia, Hungary, Sweden, Norway, Denmark and Belgium) re-introduced internal border controls due to the massive migratory flow. Malta and France introduced internal controls on the basis of 'threat on terrorism' under Art.27. As the crisis escalated, the risk increased that temporary restrictions would become permanent, and the Schengen would collapse.

\section{The Risks Posed on the Internal Market}

The Internal Market project is arguably the most significant achievement of the EU and it lies in the heart of most policy-making. However, the success of the Internal Market is under threat by the ongoing crisis. Removal of any national barriers is the key for ensuring free movement. If free movement is interrupted through national interventions, functioning of the Internal Market would be disrupted. The reintroduction of internal border checks endanger 'free movement', which is fundamental for the proper functioning of the Internal Market.

\section{The Risks Posed on the EU Integration}

The rise of anti-EU sentiment within the people of the EU presents a threat of a disastrous potential to integration. On June the $24^{\text {th }}$ of 2016 , the people of Britain voted for Britain's exit from the EU with $52 \%$. As shocking as it was, the aftermath has been a more major issue. Leaving aside the possible scenarios whether the UK will actually leave or not, the more immediate question is whether it will be the first wave of an EU disintegration era. A possible 'domino-effect' is now at the center of many speculations on the issue.

\section{The Risks Posed on EU Enlargement}

The general conditions of eligibility for EU membership is determined according to the Copenhagen Criteria, which can be examined in three categories: political, economic and legal requirements. The candidate country has to have a democratic governance, respect for the rule of law, human rights, and minority rights; functioning market economy at a certain capacity; and has to align its laws to those of the EU's. The political conditionality has become 
stricter in time, especially with the influence of 2004's fifth enlargement, which is a landmark in EU enlargement. Therefore, variations may emerge and specific conditions may be required for candidates based on their peculiarities. Enlargement theories involve two main approaches: the realist approach and the constructive approach. The realist approach evaluates admission of a new MS from a cost-benefit aspect, whereas the constructivists assess it from an identity point of view. (Yazgan, 2014:26) They basically represent economic and political approaches to enlargement. The 2004 enlargement is an example of identity based enlargement, which was celebrated at first as marking the 'reunification of Europe'. This biggest enlargement in the history of the EU has later caused, what is called an 'enlargement fatigue' in the EU.

Any economic deterioration and crisis that has an impact on economy lead to conditionality policies becoming more stringent for candidates. Such circumstances also reduce the absorption capacity of the EU, which is another barrier to enlargement. On the political side, crisis negatively effect the EU perception of Europeans and lead to what is called, xenophobia. This has escalated with the influx of refugees, mainly in connection with the fear of terrorism. (See: Chart 7) Such an opposition to foreign culture often spread to intra-Union level, which undermines the 'unity in diversity' motto of the Union. Since any admission of a new MS to the Union, requires intergovernmental decision-making procedures to be applied, high levels of political acceptability is crucial. It is however, difficult to obtain in times of crisis. On the adverse side, from the perspective of the candidate or potential candidate countries, a Union in constant crisis may no longer be a point of attraction.

\section{The Infrastructural Challanges on EU Enlargement: The Intergovernmental Mode}

Article 49 of the TEU provides the fundamental conditions with referance to the founding values of the EU identified in Art. 2 TEU for applying for EU membership, and the procedure to be followed for admission of a new Member State. An application to become a Member State is addressed to the Council, which asks the Commission to submit an opinion. The European Parliament is also notified. Then provided that the Commission submits a favourable opinion, each decision in the process (i.e. granting the applicant the 'candidate' status, opening or closing a negotiation chapter) is taken by the Council by unanimity. Accession of a new EU member is decided by a special legislative procedure, namely the consent procedure. In accordance with this procedure, the Council can adopt proposals by unanimous voting after obtaining the consent of the European Parliament, which can either accept or reject thereof by absolute majority. The European Parliament has no power to propose amendments, whereas the Council has no power to overrule the Parliament's decision. 
The decision regarding the accession of a new Member State is subject to intergovernmental method, or as Scharpf once called 'joint-decision trap'. (Sharpf, 1988) It was submitted that this method of 'self-interested bargaining' between the Member States is likely to "generate sub-optimal policy outcomes -resulting either in blockages or in inefficient lowest-denominator comprises." (Scharpf, 2006:848) However, the decision rules that reflect a pure intergovernmental perspective would eventually produce European policy choices that are likely to be "completely determined by the initial constellations of interests or political preferences among member state governments". (Falkner, 2011:3) Both Scharpf and some other scholars have since presented efforts to create routes out of the 'joint-decision trap'. (Falkner, 2011) This paper may in a humble way contribute to those efforts in a subtle capacity by emphasising the reach and importance of 'public opinion' in EU policy making and decision making phases.

\section{Public Opinion Matters!}

This paper has been designed to provide the readers with various empirical data on the public opinion towards several subjects. Why those figures matter? It is simply because, the key to the future of the EU lies to a large extent with the people of the EU. This fact has already been acknowledged or at least considered by the MSs and the EU. That is why, any action is tried to be justified before the public view. That is why the democratic deficit in the EU is tried to be remedied through structural improvements for empowerment of the Parliament, where the people are represented, and establishment of schemes such as the Citizen's Initiative to ensure direct involvement of the people. And that is also why, national governments of the MSs tend to conduct surveys to comprehend public opinion and hold referendum especially in matters relating to further integration.

Dimitrova and Kortenska argue that if the Member States' governments initiate the enlargement negotiations and make it subject to domestic political debates, there would be a chance that it could persuade at least some of the citizens who are distant to further enlargement. (2017:274) This argument intends to employ the MS governments as the main actor of a new communication route to connect with the European people. However, they also note that: "enlargment, as many other EU policies, has recently become increasingly politicized and come to the centre of domestical political debates in the member states". (2017:262) Since enlargement policies are already a topic of domestic political debate, it is difficult to see what added value could it have where the process would be initiated by the MS governments rather than the EU institutions. At the end of the day, MS governments cannot act autonoumusly despite the counter-will of their voters. Therefore, they have limited area for manouvre, which can only produce limited effect on citizen 
perceptions and decisions. Otherwise their democratic accountability may cost them the power to govern. The national governments are under the political pressure of their voters. Hatton submits a similar view, albeit on refugee and asylum policy, and notes that: (2015:624)
"[...] greater welfare could be attained if refugee and asylum policy was determined centrally, so that the public good element is taken fully into account. That would require an even more radical shift away from national decision-making and towards decision-making at the EU level. As we have seen, national governments seem to be reluctant to cede control of asylum policies, perhaps because they fear that this would make them even more unpopular."

As citizen attitudes gain more power as a determinant concerning EU policies, both the national governments of the Member States and the EU policy makers are induced to act in the shadow of the constraining influance of the perceptions of the European citizens. It is also worth mentioning that the two major decision-making bodies of the EU, namely the Council and the Parliament, are under the indirect (for the Council) or direct (for the Parliament) influance/ dominance of the EU citizens. Therefore it is more crucial than ever that, the message of the people who are increasingly drawn to more nationalistic internal policies should be heard and the reasons should be duly considered. It is only possible to reverse the negative public opinion, if the underlying reasons are accurately identified and properly remedied where feasible.

\section{The 'Asymmetric Information' Problem and the Formation of the EU Public Opinion}

Another problem lies with the political manipulation of people who are already feeling the strain of the never-ending crisis that the EU has been facing for the last decade. The Eurosceptic national policies and the political supporters of such views make the best of it and gain scores with their populist opinions and propaganda, which sometimes involve inaccurate or misleading information regarding the EU. At the end of the day, it is a competition for power; in this case both amongst the national political parties, and also between the EU and the MSs. It is only natural that people who are not happy with the way they are governed to incline to alternatives. Democracy dictates to respect to the choices of people. However, to maximise the efficiency of democracy it's crucial to provide the voters with correct and sufficient information. Otherwise democracy may become a legitimate weapon for unintended policies to be put into practice. The power of democracy appears through 'educated choices'. Here the EU is responsible to provide the public with correct and sufficient information regarding its structure, operation, aims and policies. 
As can be observed from the surveys, until now the EU has failed to deliver its part in reaching to its citizens. This leads to exposure to asymmetric information for the people and hence may cause flawed choices to be made. In fact this was probably the case after Brexit results were out. According to a statement by Google Trends, by the time the news that the 'leave' campaign had been victorious, there had been a $250 \%$ rise in the number of searches for "What happens if we leave the EU?" while "What is the EU?" was the secondmost-popular question being asked in relation to the Brexit in the hours since the decision to leave the EU had been announced. (The Washington Post, 2016) We do not know whether the 'leave' decision would have change should the public be better informed, but there were many manipulative and misleading arguments put forward at the time of the campaign. (The Guardian, 2016) In any case the EU is partly to blame for the results.

Akerlof is a famous economist, who won the Nobel Prize in 2001 with his research related to asymmetric information. (Akerlof: 1970) His theory simply suggests that the uninformed buyer's price creates an adverse selection problem, which eventually leads to a market collapse. In his illustration over cars, he classifies used cars as 'good cars' and 'lemons' (bad cars). However, the buyer is not in a position to know exactly, which category the car on sale belongs to, whereas the seller knows. This asymmetric information causes uncertanity on behalf of the buyer, which prevents him to pay the true value of a high-quality car, even if the car in question is one of the 'good' ones. As they cannot get the true value, the sellers of the good cars, avoid selling theirs, to avoid loss. This leaves us with a market dominated by 'lemons', that eventually leads to market collapse.

In analogy with Akerlof's "The Market for 'Lemons"” theory:

- The EU have problems with reaching to its people, which expose European people to asymmetric information.

- As choices based on assymetric information increase, better informed choices (in analogy with high-quality cars) gradually lose their attraction and eventually leave the political arena (the market).

- The fact that people are left with 'bad' and 'worse' choices only, the deterioration causes the EU politics to collapse.

Both integration and enlargement policies would perhaps be the first ones to be exposed to the adverse affect by this asymmetric information problem. The integration process, which may be defined as the primary purpose of the Union, would initially stop and possibly continue in the opposite way as a disintegration process. In an environment of no-integration or disintegration, enlargement would be a remote and even a grotesque policy. This can be noted 
both for the supply (MSs) and demand (candidate states) sides of the market, defining in economic terms.

\section{Possible Solutions}

As has been given in this paper briefly, until now the respond by the EU as regards the challenges posed by various crisis has been 'more Europe'. However, considering the attitude of the people towards the EU, 'more Europe' option seems a bit distant. Still, should the inaction of the EU continues, the political choices of people will eventually drag the EU to disintegration. Here are a few options for the EU on how to achieve 'more Europe'.

Firstly, more Europe aim can be achieved by reaching out to the people and persuading them. If the EU wants to maintain its 'ever closer Union' purpose it must improve ways to connect with its citizens. Key to closer Union is to be closer to citizen!

Alternatively it can be done in spite of the people's will, which probably cannot be maintained in the longer run. The national governments would not dare to act against the will of the people who elected them, and would not gamble with their political career.

Another option to consider is that: sometimes less is more! Maybe less Europe is the answer this time?

Finally, as Syrus says: Anyone can hold the helm when the sea is calm. (quotery.com) 


\section{The Refugee Crisis in Figures}

\section{Chart 1}

\section{Number of asylum seekers in Europe surges to record 1.3 million in 2015}

Annual number of asylum applications received by EU-28 countries, Norway and Switzerland, 1985 to 2015

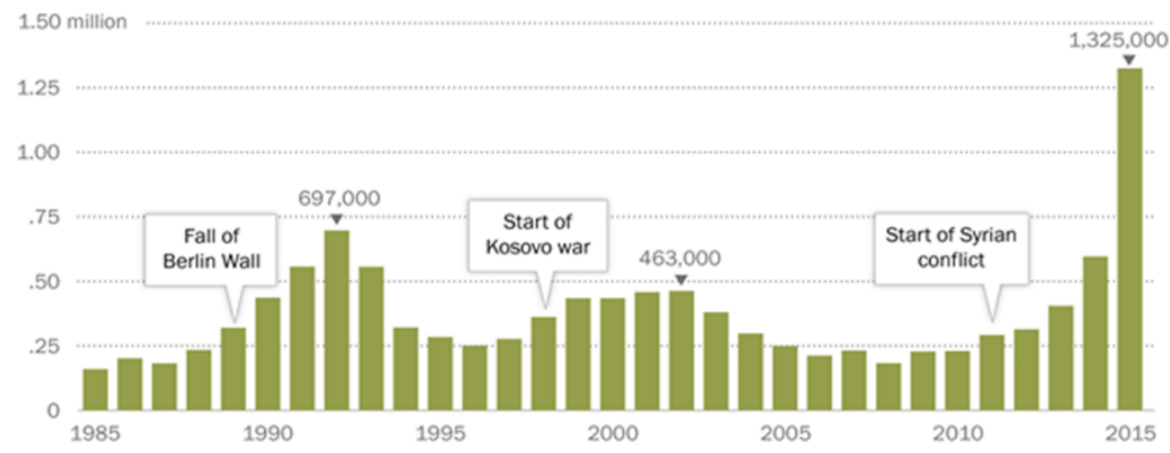

Note: "Europe" consists of the EU-28, Norway and Switzerland. Asylum seeker definitions varied by European country prior to 2008. Numbers for asylum applications since 2008 are based on first-time applicants and do not include appeals or transfer of applications between countries. See methodolog for more details. Data on asylum applications is missing for some countries in some years. See Appendix A for lis. of countries with missing data. All countries that are part of the EU today are included in previous years' data even though several were not part of the European Union in earlier years. Rounded to nearest thousand.

Source: Pew Research Center analysis of Eurostat data, accessed June 22, 2016.

"Number of Refugees to Europe Surges to Record 1.3 Million in 2015"

PEW RESEARCH CENTER

Source: Pew Research Centre (August 2016) 


\section{Chart 2}

\section{Europe's asylum seekers did not equally disperse across countries}

Number of first-time asylum applications in $2015 \mathrm{per}$ 100, 000 people in the country's population

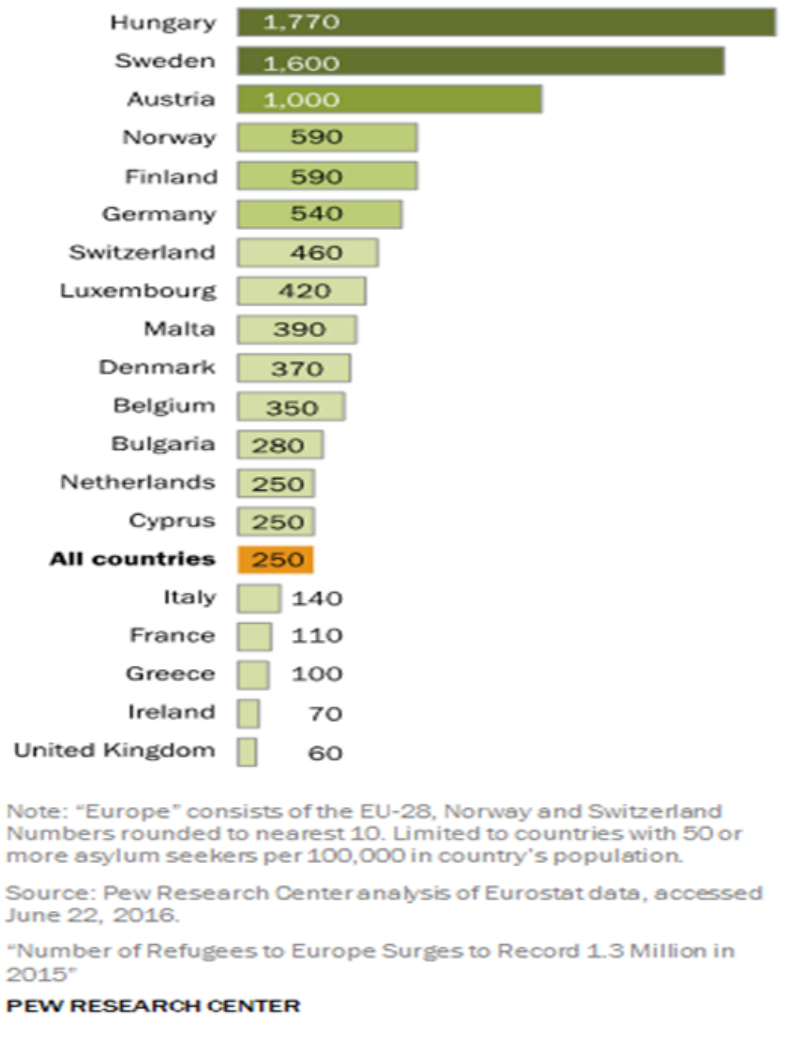

Source: Pew Research Centre (August 2016) 


\section{Chart 3}

Number of asylum seekers from Syria, Afghanistan and Iraq more than quadrupled between 2013 and 2015

Number of first-time asylum applications to Europe from each country of origin, in thousands

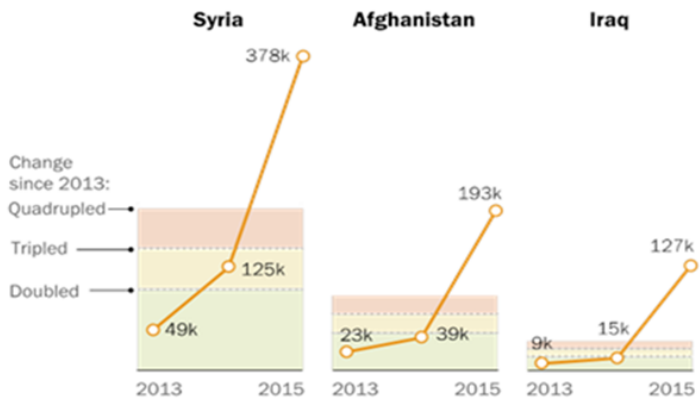

Note: "Europe" consists of the EU-28, Norway and Switzerland. Rounded to nearest thousand.

Source: Pew Research Center analysis of Eurostat data, accessed June 22, 2016.

"Number of Refugees to Europe Surges to Record 1.3 Million in 2015"

PEW RESEARCH CENTER

Source: Pew Research Centre (August 2016)

\section{Euroscepticism in Figures}

\section{Chart 4}

\section{EU favorability varies widely in Europe}

Views of EU

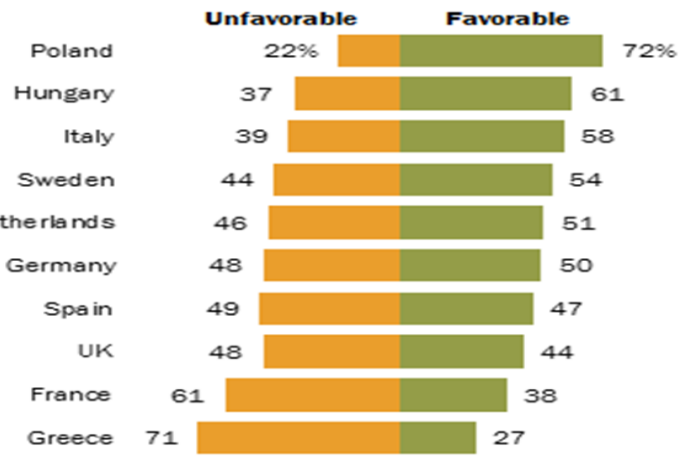

Source: Spring 2016 Global Attitudes Survey. Q10c.

"Euroskepticism Beyond Brexit"

PEW RESEARCH CENTER

Source: Pew Research Centre (August 2016) 


\section{Chart 5}

\section{Disagreement on 'ever closer' union}

Which statement best describes your views about the future of the European Union?

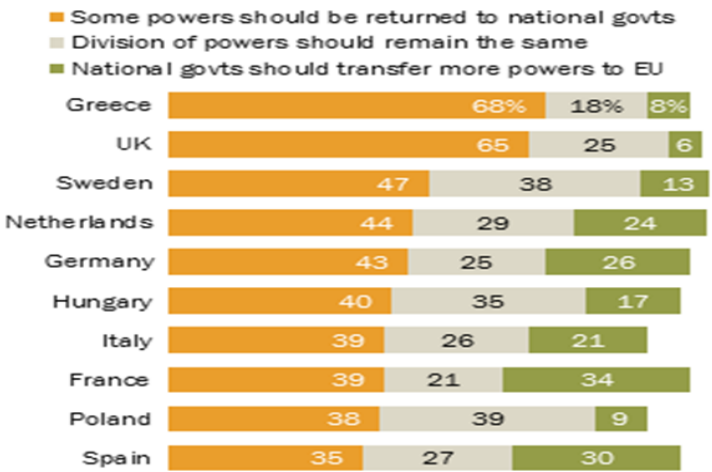

Note: Don't know responses not shown.

Source: Spring 2016 Global Attitudes Survey. Q49.

"Euroskepticism Beyond Brexit"

PEW RESEARCH CENTER

Source: Pew Research Centre (August 2016)

\section{Chart 6}

\section{Overwhelming majorities in Europe unhappy with EU's handling of refugees}

Do you __ of the way the European Union is dealing with the refugee issue?

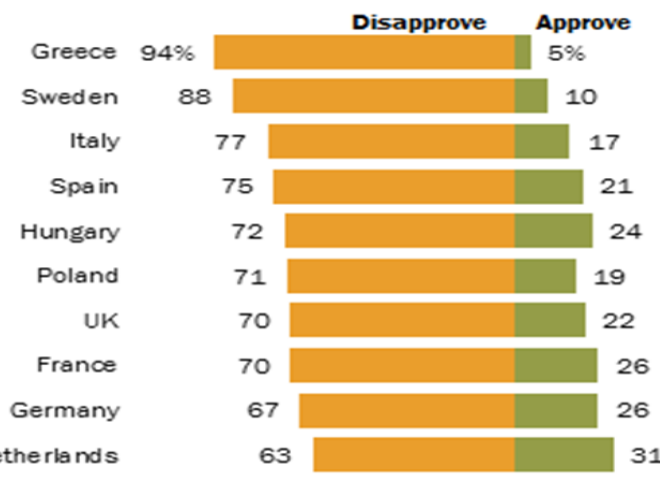




\section{Chart 7}

\section{Many Europeans concerned refugees will increase domestic terrorism}

Refugees will in our country

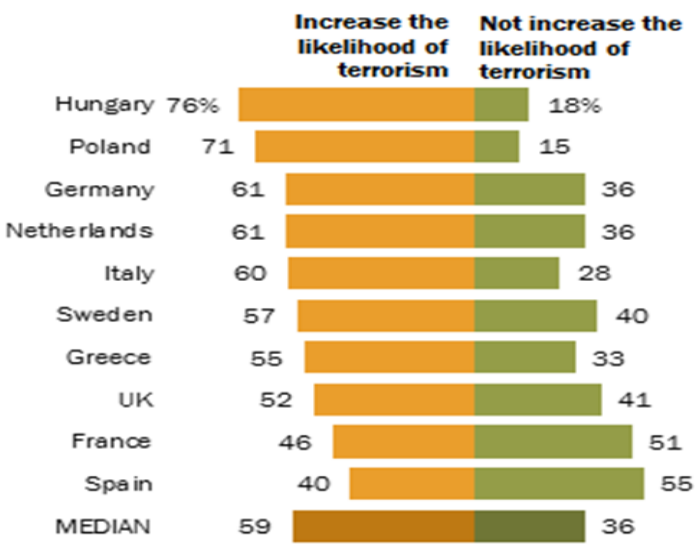

Source: Spring 2016 Glo bal Attitudes Survey.

PEW RESEARCH CENTER

Source: Pew Research Centre (August 2016)

\section{Chart 8}

QA8a I would like to ask you a question about how much trust you have in certain institutions. For each of the following institutions, please tell me if you tend to trust it or tend not to trust it.

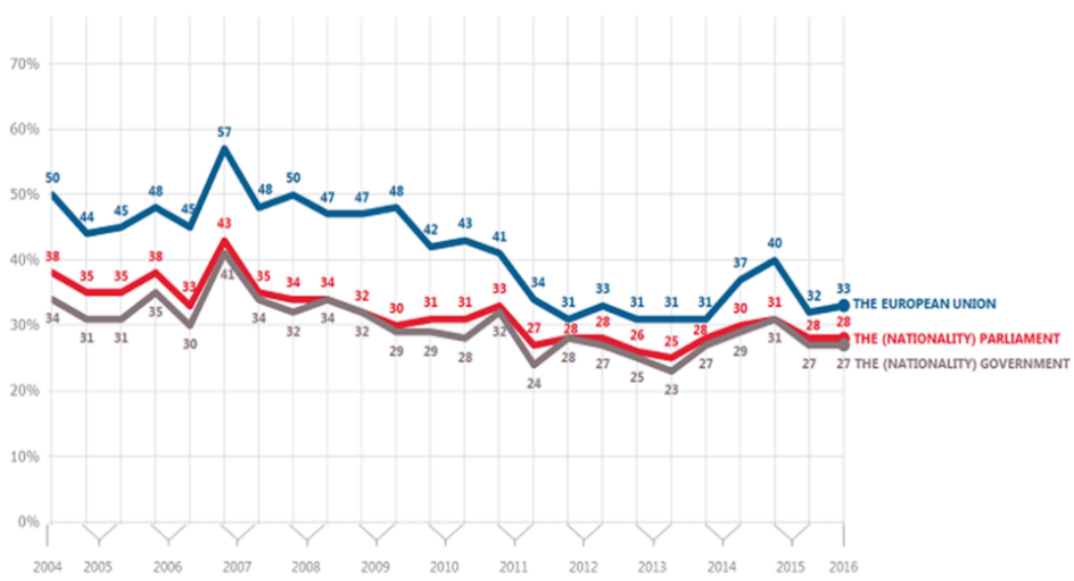

Source: Standard Eurobarometer 85 (Spring 2016):14 


\section{Chart 9}

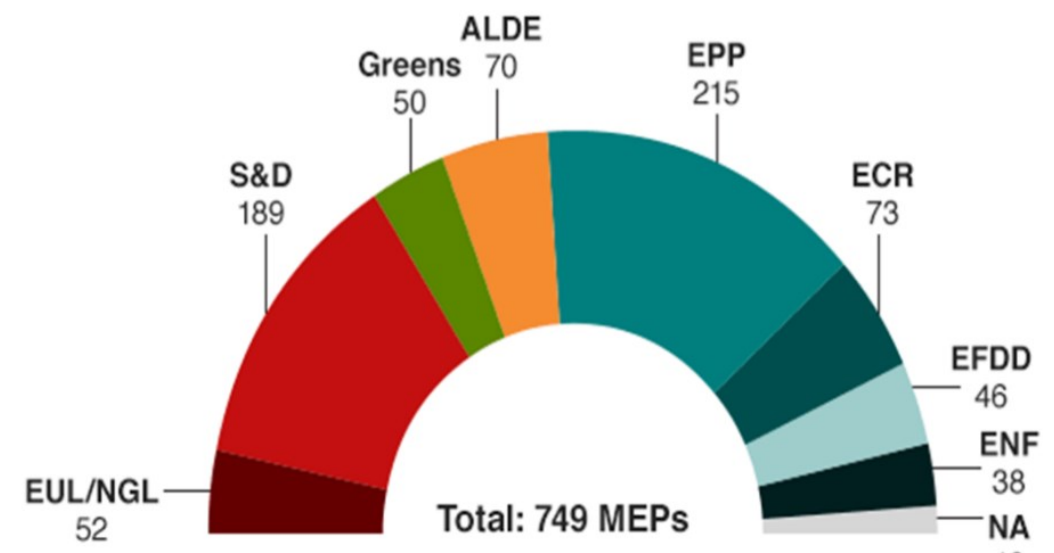

$B B C$

Source: How Eurosceptic is the new European Parliament, BBC (2014)

EPP - European People's Party (centre-right)

S\&D - Progressive Alliance of Socialists and Democrats in Europe (centre-left)

ALDE - Alliance of Liberals and Democrats for Europe (liberal)

EUL/NGL - European United Left-Nordic Green Left (left-wing and Eurosceptic)

Greens/EFA-Greens/European Free Alliance (Greens and regionalists/nationalists)

ECR - European Conservatives and Reformists Group (right-wing)

EFDD - Europe of Freedom and Direct Democracy (Eurosceptic)

ENF - Europe of Nations and Freedom Group (right-wing)

NI - Non-attached (stands for "non-inscrits" - MEPs not in any group, includes many Eurosceptics or anti-EU) 


\section{Chart 10}

Rise of nationalism in Europe: Results of most recent national elections

$\%$ of votes won by nationalist party

1-8 $\square$ 9-18 $\square 19-28 \square 29+$

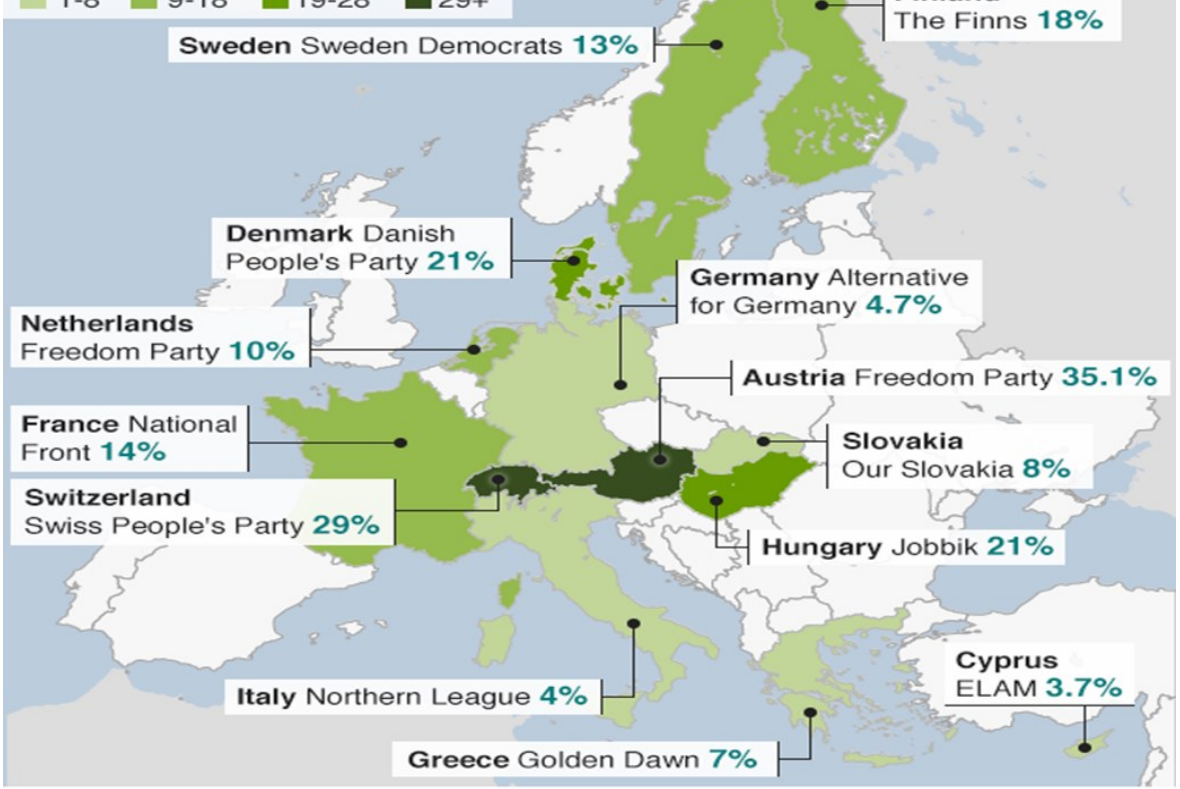

In many countries nationalists got higher scores in European Parliament elections and opinion polls

BBBC

Source: BBC (May 2016) 


\section{References:}

Akerlof, G. A. (1970) "'The Market for Lemons: Quality Uncertainty and the Market Mechanism”, The Quarterly Journal of Economics, 84 (3): 488-500.

Barber, T. (2010) "Greece condemned for falsifying data", Financial Times, 12 January 2010, <https://www.ft.com/content/33b0a48c-ff7e-11de-8f5300144feabdc0>, (8 September 2017).

BBC (2014) "How Eurosceptic is the new European Parliament", 01 July 2014, $<$ http://www.bbc.com/news/world-europe-28107633>, (8 September 2017).

BBC (2016) "The Rise of Nationalism in Europe", 01 May 2016, $<$ http://www.bbc.com/news/world-europe-36182511>, (8 September 2017).

Carrera, S., Blockmans, S., Gros, D., Guild, E. (2015) “The EU's Response to the Refugee Crisis -Taking Stock and Setting Policy Priorities", CEPS Essay (Centre for European Policy Studies), No: 20/16 December 2015.

CVCE.EU (2017) “The Luxembourg Compromise (1966)", <https:/www.cvce. eu/en/education/unit-content/-/unit/d1cfaf4d-8b5c-4334-ac1d-0438f4a 0d617/a9aaa0cd-4401-45ba-867f-50e4e04cf272>, (8 September 2017).

Dimitrova, A., Kortenska, E. (2017) "What do citizens want? And why does it matter? Discourses among citizens as opportunities and constraints for EU enlargement”, Journal of European Public Policy, 24 (2): 259-77.

Dinan, D. (2016) "Coping with Crisis: The Role of the European Council President”, Fordham International Law Journal, 2016 (39): 1225.

European Council on Foreign Relations, Policy Memo (2013) "The ContinentWide Rise of Euroscepticism” (ECFR/79), May 2013, <http://www.ecfr. eu/page//ECFR79_EUROSCEPTICISM_BRIEF_AW.pdf $>$, (2 November 2017).

European Foundation for the Improvement of Living and Working Conditions Eurofound (2017) "Luxembourg Compromise", 11 March 2007, $<$ https://www.eurofound.europa.eu/observatories/eurwork/industrialrelations-dictionary/luxembourg-compromise>, (8 September 2017).

Falkner, G. (2011) “Chapter 1: Introduction: The EU's Decision Traps and their Exits: A Concept for Comparative Analysis" in Gerda FALKNER (ed.) EU's Decision Traps: Comparing Policies (New York, OUP), pp.1-17.

Falkner, G. (2011) EU's Decision Traps: Comparing Policies, (ed.) (New York, OUP).

Gilbert, M. (2012) European Integration: A Concise History, (Plymouth: Rowman \& Littlefield Publishers). 
Hakhverdian, A. Van Elsas, E., Van Der Brug, W., Kuhn, T., (2013) "Euroscepticism and Education: A Longitudinal Study of 12 EU Member States, 1973-2010”, European Union Politics, 14 (4): 522-41.

Hatton, T. J. (2015) "Asylum Policy in the EU: the Case for Deeper Integration”, CESifo Economic Studies, 61 (3): 605-37.

Hobolt, S. B., De Vries, C. (2016) “Turning Against the Union? The Impact of the Crisis on the Eurosceptic Vote in the 2014 European Parliament Elections", Electoral Studies, 2016 (44): 504-14.

IOM Press Release (2017) "Global Migrant Deaths Pass 5.200", 28 October 2016, <https://www.iom.int/news/global-migrants-deaths-pass-5200>, (2 October 2017).

IOM, GMDAC (2017) "The Global Migration Trends Factsheet-2015", February 2017, <https://publications.iom.int/system/files/global_migration trends_2015_factsheet.pdf $>$, (8 September 2017).

Jolly, D. (2017) “2009 Greek Deficit Revised Higher”, The New York Times, 15 November 2010, <http://www.nytimes.com/2010/11/16/ business/global/ 16deficit.html>, (8 September 2017).

Kindreich, A. "The Greek Financial Crisis (2009-2016)", 20 July 2017, $<$ https://www.econcrises.org/2017/07/20/the-greek-financial-crisis-20092016/>, (8 September 2017).

Pew Research Centre (2016) "European Opinions of the Refugee Crisis in 5 Charts", 16 September 2016, <http://www.pewresearch.org/facttank/2016/09/16/european-opinions-of-the-refugee-crisis-in-5-charts/>, September 2017).

Pew Research Centre (2016) "Euroscepticism Beyond Brexit", 07 June 2016, $<$ http://www.pewglobal.org/2016/06/07/euroskepticism-beyond-brexit/> (8 September 2017).

Pew Research Centre (2016) "Number of Refugees to Europe Surges to Record 1.3 million in 2015", 02 August 2016, <http://www.pewglobal.org /2016/08/02/number-of-refugees-to-europe-surges-to-record-1-3-million-in2015/>, (8 September 2017).

Scharpf, F. W. (1988) "The Joint-decision trap: Lessons from German Federalism and European Integration", Public Administration, 66 (3): 23978.

Scharpf, F. W. (2006) "The Joint-Decision Trap Revisited", Journal of Common Market Studies, 44 (4): 845-64. 
Skynews (2017) "Germany: No Limit To Refugees We'll Take In", 05 September 2015, <http://news.sky.com/story/germany-no-limit-to-refugeeswell-take-in-10347281>, (8 September 2017).

Standard Eurobarometer 85 (2016), "Public Opinion in the European Union", (Spring 2016).

The Guardian (2017) "Brexit Campaigners accused of dishonesty over EU budget", 11 March 2016, <https://www.theguardian.com/politics/ 2016/mar/11/brexit-campaigners-accused-of-dishonesty-over-eu-budget>, (08 September 2017).

The Latin Library Website, "Publilius SYRUS", <http://thelatinlibrary. com/syrus.html>, (8 September 2017).

The Quotery Website, (2014) <http://www.quotery.com/quotes/anyone-canhold-the-helm-when-the-sea-is-calm/>, (8 September 2017).

The Washington Post (2017) "The British are frantically Googling what the E.U. is, hours after voting to leave it", 24 June 2016, $<$ https://www.washingtonpost.com/news/the-switch/wp/2016/06/24/thebritish-are-frantically-googling-what-the-eu-is-hours-after-voting-to-leaveit/?utm_term $=.5959995 \mathrm{cc} 7 \mathrm{a} 2>$, (8 September 2017).

UNHCR (2017) "Global Trends - Forced Displacement in 2015” 20 June 2016, $<$ http://www.unhcr.org/576408cd7.pdf>, (2 October 2017).

Wearden, G. (2017) "Greek Debt Crisis: Timeline”, 05 May 2010, The Guardian, <https://www.theguardian.com/business/2010/may/05/greecedebt-crisis-timeline>, (08 September 2017).

Yataganas, X. A. (2001) "The Treaty of Nice - The Sharing of Power and the Institutional Balance in the European Union-A Continental Perspective" Jean Monnet Working Paper 1/01, <http://www.jeanmonnetprogram.org/ archive/papers/01/010101.html>, (8 September 2017).

Yazgan, H. (2014) "Ekonomik ve Siyasi Krizlerin AB Genişlemelerine Etkileri" in Belgin AKÇAY (ed), Türkiye-AB İlişkileri Yeni Gündem, (Ankara: Seçkin), pp. 25-34. 